\title{
Urea nutrition of young maize and sugar-beet plants with emphasis on ionic balance and vascular transport of nitrogenous compounds
}

\author{
M. L. van Beusichem and J. J. Neeteson* \\ Department of Soil Science and Plant Nutrition, Agricultural University, De \\ Dreijen 3, NL 6703 BC Wageningen, Netherlands
}

Accepted: 22 July 1982

Key-words: acidification, alkaline uptake pattern, ammonium nutrition, urea uptake, nutrient absorption, N metabolism, xylem transport, Beta vulgaris, Zea mays

\section{Summary}

In a water culture experiment ammonium and urea as nitrogen sources for maize and sugar-beet plants were compared. The form of nitrogen nutrition did not significantly affect the production of dry matter, but both plant species absorbed considerably more nitrogen when they were supplied with ammonium.

In all cases experimental data of cumulative net proton extrusion by the roots showed a close agreement with calculated values for excess absorption of supplied nutritive cations, thus providing evidence for the ability of maize and sugar-beet plants to absorb urea as an undestructed molecule, at a rate sufficient for growth.

The xylem exudates of both ammonium- and urea-supplied maize plants were found to be almost free from these nitrogen sources, allowing the conclusion that urea and ammonium are almost quantitatively metabolized in the roots.

Differences in the fractionation of organic nitrogen compounds in the xylem exudates of ammonium- and urea-supplied maize plants allowed the assumption that urea is assimilated via a metabolic pathway other than enzymatic breakdown followed by incorporation of ammonium.

\section{Introduction}

The form of nitrogen nutrition has an important impact on the nutrient-element balance in plants. Many investigations have been carried out to study the effects

* Present address: Institute for Soil Fertility, P.O. Box 30003, NL 9750 RA Haren (Gr.), Netherlands. 
of nitrate or ammonium nutrition on the uptake of different cations and anions, the ionic balance, organic acid and carbohydrate metabolism of different hydroponically grown plant species (Breteler, 1973; Chouteau, 1963; Coïc et al., 1962; Clark, 1936; Dijkshoorn et al., 1968; Houba et al., 1971; Kirkby, 1968, 1969; Kirkby \& Hughes, 1970). The number of publications concerning comparative studies of nitrogen sources, including urea, is very limited (van Beusichem \& van Loon, 1978; DeKock, 1970; Kirkby \& Mengel, 1967, 1970; Wallace $\&$ Ashcroft, 1956). One of the experimental problems encountered in urea nutrition research is the chemical oxidation or enzymatic breakdown of this compound to ammonium carbonate or ammonia (Court et al., 1964; Gausman \& Batteese, 1966), followed by a preferential absorption of ammonium by the plant roots (van Beusichem \& van Loon, 1978; Ostromeçka, 1961). When urea is compared with other nitrogen sources with respect to its effect on the nutrientelement balance in plants, decomposition of this compound must be avoided or at least be quantified.

From studies in soils it is known that urease inhibitors cannot prevent ureolysis completely (Kiss et al., 1975). Also in nutrient solutions urea hydrolysis can occur (Müller, 1961) and this confuses the effect of urea absorption and metabolization on plant characteristics. Negative checks on the ammonium content in nutrient solutions supplied with urea are not sufficient to conclude that all nitrogen was taken up as urea (Kirkby \& Mengel, 1967), because of the preferential uptake of ammonium from urea-ammonium mixtures which results in a very low, if detectable, ammonium concentration in the nutrient solution. The flushing technique, described by Wallace \& Ashcroft (1956), is not a guarantee for urea uptake either. The slight increase of the $\mathrm{pH}$ of the urea-containing nutrient solutions, observed by these authors, was probably a reflection of the urea hydrolysis process.

In short-term experiments urea uptake characteristics can be investigated with ${ }^{14} \mathrm{C}$-urea (Mitsui \& Kurihara, 1962) or twofold ${ }^{15} \mathrm{~N}$-labelled urea (Hentschel, 1976). Determination of both urea and radio activity present in the xylem exudate of urea-supplied bean plants allowed the conclusion that urea was taken up as an undestructed molecule and was not metabolized in the roots (Hentschel, 1976). Similar conclusions were drawn by Mitsui \& Kurihara (1962) after comparison of uptake of ${ }^{14} \mathrm{C}$ of urea and ammonium carbonate and its incorporation in ethanol soluble constituents of wheat roots and rice plants.

The only way to avoid urea decomposition in long-term water culture experiments seems to be the application of an intensive renewing scheme. Van Beusichem \& van Loon (1978) described an experiment in which ammonium, nitrate, and urea nutrition of 26-day old maize plants were compared under greenhouse conditions, without renewing of the nutrient solutions. From data about the dry matter production, the ionic balance, the nitrogen content and the amounts of acidity or alkalinity which were necessary to keep the $\mathrm{pH}$ constant, both in urea containing nutrient solutions with and without plants, they concluded that under such experimental conditions in the urea treatment all nitrogen was taken up as ammonium by these plants. In the experiment described in the present pu- 
blication the influence of intensive renewing of a urea- or ammonium-containing nutrient solution on the dry matter production, nitrogen content and ionic balance of young maize and sugar-beet plants, in relation to acidification of the nutrient solution, was studied. Furthermore, the effect of these nitrogen sources on the longitudinal translocation of nitrogenous compounds in maize plants was investigated.

\section{Materials and methods}

\section{Plant cultivation}

Experiment 1. Seeds of Beta vulgaris L. cv. Polyrave were germinated in quartz sand moistened with demineralized water. After three weeks the seedlings were transferred to Mitscherlich pots (inner diameter $20 \mathrm{~cm}$, height $22 \mathrm{~cm}$ ) all containing 7 litres of a well-aerated $0.5 \mathrm{mmol} / \mathrm{I}$ calcium sulphate solution. The pots were covered with perforated lids in which the seedlings were held in place by means of foam plastic (4 seedlings/pot).

Seeds of Zea mays L. cv. Prior were germinated in sieves filled with wetted gravel. Each sieve was placed on a Mitscherlich pot containing a well-aerated $0.5 \mathrm{mmol} / \mathrm{l}$ calcium sulphate solution.

All pots ( 16 with sugar-beet and 12 with maize seedlings) were placed in a growth cabinet where the experimental conditions were: temperature $20^{\circ} \mathrm{C}$, photoperiod $14 \mathrm{~h} \mathrm{day}^{1}$, light intensity $40.3 \mathrm{~W} \mathrm{~m}^{-2}$, and relative air humidity 70 $75 \%$. One week after germination the number of maize seedlings was reduced to 15 per pot. At the same time the calcium sulphate solution in all pots was replaced by a complete nutrient solution which contained either ammonium or urea as the sole source of nitrogen. The acidity of both nutrient solutions was adjusted at $\mathrm{pH}$ 5.5. The composition of the nutrient solutions is given in Table 1. In all pots the nutrient solutions were renewed daily. The amounts of acidity produced by the plants were determined daily by back titration of the used solutions to the initial $\mathrm{pH}$ value with 0.1000 or $0.2000 \mathrm{~mol} / 1 \mathrm{NaOH}$ by means of an automatic titration equipment (Radiometer PHM 64 pH meter/TTT 60 titrator), operating an automatic burette (Radiometer ABU 13). The plants were grown under constant climatic conditions for a period of 21 (maize) or 28 (sugarbeet) days.

Experiment 2. For the exudation experiment seedlings of Zea mays L. cv. Prior, which were germinated for two weeks in quartz sand moistened with demineralized water, were transferred to two 65 -litre boxes (surface $5000 \mathrm{~cm}^{2}$, height 13 $\mathrm{cm}$ ). Each box contained 60 litres of a 0.5 -strength Hoagland solution (Table 1) which was circulated and consequently aerated by an electric pump with a capacity of about 15 litres per minute. Each box contained 12 selected maize plants. The boxes were placed in a growth chamber maintained at $22^{\circ} \mathrm{C}$. The light intensity during the $14-\mathrm{h}$ photoperiod was $37.5 \mathrm{~W} \mathrm{~m}^{-2}$ while the relative air humidity varied between 70 and $75 \%$. The $\mathrm{pH}$ of the nutrient solutions was 
Table 1. Chemical composition (meq $1^{-1}$ ) of the nutrient solutions used in the experiments.

\begin{tabular}{lcccccccccc}
\hline & $\mathrm{Urea}^{1} \mathrm{~K}$ & $\mathrm{Na}$ & $\mathrm{Ca}$ & $\mathrm{Mg}$ & $\mathrm{NH}_{4}$ & $\mathrm{H}_{2} \mathrm{PO}_{4} \mathrm{Cl}$ & $\mathrm{NO}_{3}$ & $\mathrm{SO}_{4}$ \\
$\begin{array}{l}\text { Experiment l } \\
\text { Ammonium solution }\end{array}$ & - & 1.0 & 0.5 & 0.5 & 0.5 & 2.0 & 1.0 & 0.5 & - & 3.0 \\
Urea solution & 2.0 & 1.0 & 0.5 & 0.5 & 0.5 & - & 1.0 & 0.5 & - & 1.0 \\
& & & & & & & & & & \\
$\begin{array}{l}\text { Experiment 2 } \\
\text { 0.5 Hoagland soln }\end{array}$ & - & 3.0 & - & 5.0 & 2.0 & - & 0.5 & - & 7.5 & 2.0 \\
$\begin{array}{l}\text { Zero-N solution } \\
\text { Ammonium solution }\end{array}$ & - & 3.0 & - & 5.0 & 2.0 & - & 0.5 & 5.0 & - & 4.5 \\
Urea solution & 4.0 & 3.0 & - & 5.0 & 2.0 & 4.0 & 0.5 & 5.0 & - & 8.5 \\
\hline
\end{tabular}

Trace elements in all solutions ( $\mathrm{mg}^{-1}$ ): $\mathrm{Fe} 4.6 ; \mathrm{B} 0.5 ; \mathrm{Mn} \mathrm{0.5;} \mathrm{Zn} \mathrm{0.05;} \mathrm{Cu} 0.02 ; \mathrm{Mo} 0.01$.

${ }^{1} \mathrm{As} \mathrm{NH}_{4}$ equivalent.

measured daily and kept between 5.5 and 6.0 by adding appropriate amounts of $0.1 \mathrm{~mol} / 1 \mathrm{HCl}$. The nutrient solutions were renewed weekly. After 35 days of growth the solutions were replaced by a 0.5 -strength Hoagland solution without nitrogen (Table 1). After a further 5 days of growth on this zero- $\mathrm{N}$ medium the boxes were filled with complete nutrient solutions which contained either urea or ammonium as the sole source of nitrogen (Table 1). At the same time all plants were decapitated about $5 \mathrm{~cm}$ above the root system. About $10 \mathrm{~cm}$ of PVC tubing was attached to the cut stump to allow the exudate to collect. During 32 hours xylem sap was removed at 30-minute intervals, using a syringe, and stored in plastic vials at $-20^{\circ} \mathrm{C}$ immediately after sampling.

\section{Analytical methods}

Experiment 1 . At harvest time all plants were separated into shoots and roots prior to chemical analysis. The roots were washed for 1 minute in $0.01 \mathrm{~mol} / \mathrm{l}$ $\mathrm{HCl}$ and then rinsed twice with demineralized water. The weighed fresh plant material was partly dried at $70^{\circ} \mathrm{C}$ for a period of 24 hours. Subsequently, the dry weights were determined and the samples were ground for analyses. Subsamples were analysed for total nitrogen, potassium, sodium, calcium, magnesium, phosphate, chloride, nitrate, and sulphate. These analyses were performed as described previously (van Beusichem, 1981). Free ammonium was determined by steam distillation in a $1: 1(\mathrm{v} / \mathrm{v})$ mixture of $0.05 \mathrm{~mol} / 1 \mathrm{Na}_{2} \mathrm{~B}_{4} \mathrm{O}_{7}$ and $0.1 \mathrm{~mol} / 1$ $\mathrm{NaOH}(\mathrm{pH} \mathrm{11)}$ in a Parnas-Wagner apparatus after extraction of fresh plant material with cold $70 \%(\mathrm{v} / \mathrm{v})$ ethanol in a cooled Bühler homogenizer. The distillate was collected in $1 \% \mathrm{H}_{3} \mathrm{BO}_{3}(\mathrm{w} / \mathrm{v})$ followed by automatic titration with $0.0100 \mathrm{~mol} / 1 \mathrm{KH}\left(\mathrm{IO}_{3}\right)_{2}$.

All results represent the mean values of three (maize) or four (sugar-beet) replicates.

Experiment 2. Xylem exudates collected from 4 plants over a 8-h period were taken together and treated as one sample. At the end of the experiment ( $32 \mathrm{~h}$ af- 
ter decapitation) the exudate samples were weighed and the individual root systems were dried at $70^{\circ} \mathrm{C}$ to constant weight.

The xylem exudates were analysed for total nitrogen, glutamine, asparagine, ammonium, urea, $\mathrm{pH}$, and ash alkalinity. For the total nitrogen determination the sap was destructed at $360-380^{\circ} \mathrm{C}$ in a $30: 1(\mathrm{v} / \mathrm{w}) \mathrm{H}_{2} \mathrm{SO}_{4}$-salicylic acid mixture and $0.2 \mathrm{~g} \mathrm{Se-mixture} \mathrm{(Merck} \mathrm{8030)} \mathrm{after} \mathrm{nitration} \mathrm{at} \mathrm{room} \mathrm{temperature} \mathrm{for} \mathrm{at}$ least $2 \mathrm{~h}$ (Eastin, 1978). The amide groups of glutamine were hydrolyzed at $100{ }^{\circ} \mathrm{C}$ for $3 \mathrm{~h}$ in a phosphate buffer at pH $6.5\left(6.800 \mathrm{~g} \mathrm{KH}_{2} \mathrm{PO}_{4}+0,556 \mathrm{~g} \mathrm{NaOH}\right.$ per litre), while treatment of the exudate with $0.625 \mathrm{~mol} / 1 \mathrm{H}_{2} \mathrm{SO}_{4}$ at $100^{\circ} \mathrm{C}$ for 3 $\mathrm{h}$ resulted in hydrolysis of the amide groups of glutamine + asparagine. Ammonium in the exudates was determined as described above. In the hydrolysates and the destruates ammonium was determined by steam distillation in $0.1 \mathrm{~mol} / 1$ $\mathrm{NaOH}$ (glutamine) or $12,5 \mathrm{~mol} / 1 \mathrm{NaOH}$ (glutamine + asparagine, and total nitrogen).

Urea in the exudates was determined colorimetrically, using acidified diacetyl monoxime and thiosemicarbazide as reagents and phenylmercuric acetate as a urease inhibitor (Kyllingsbaek, 1975).

The excess cation content in the exudates (ash alkalinity) was determined by treatment of $1 \mathrm{ml}$ of exudate with $5.0 \mathrm{ml} 0.100 \mathrm{~mol} / 1 \mathrm{NaOH}$ at $550^{\circ} \mathrm{C}$ for $3 \mathrm{~h}$. After cooling to room temperature $10.0 \mathrm{ml} 0.1000 \mathrm{~mol} / 1 \mathrm{HCl}$ was added and the excess acid was titrated at $60-80^{\circ} \mathrm{C}$ to $\mathrm{pH} 5.0$ with $0.1000 \mathrm{~mol} / 1 \mathrm{NaOH}$, with methyl red-bromocresol green as an indicator.

All results represent the mean values of three replicates.

\section{Results}

\section{Experiment 1}

\section{Production of dry matter}

In Table 2 dry matter yields of maize and sugar-beet plants, grown with ammonium or urea as the sole source of nitrogen nutrition, are compared. The small (not significant) positive effect of ammonium nutrition on the yield of stems + leaves in combination with a reverse effect on the production of roots resulted in a higher shoot-root ratio for ammonium-supplied plants as compared with

Table 2. Dry matter yields ( $\mathrm{g} / 100$ plants) of shoots and roots and shoot-root ratios of maize and sugar-beet plants, grown on a nutrient solution with either ammonium or urea as the sole nitrogen source.

\begin{tabular}{|c|c|c|c|c|}
\hline & \multicolumn{2}{|l|}{ Maize } & \multicolumn{2}{|c|}{ Sugar-beet } \\
\hline & $\mathrm{NH}_{4}$ & urea & $\mathrm{NH}_{4}$ & urea \\
\hline Shoots & 107.34 & 92.90 & 15.49 & 14.97 \\
\hline Roots & 38.17 & 46.80 & 5.14 & 5.85 \\
\hline Whole plants & 145.51 & 139.70 & 20.63 & 20.82 \\
\hline Shoot:root & 2.81 & 1.99 & 3.01 & 2.56 \\
\hline
\end{tabular}


Table 3. Nitrogen content ( $\mathrm{mmol} / \mathrm{kg} \mathrm{DM}$ ) of shoots, roots and whole maize and sugar-beet plants, grown on a nutrient solution with either ammonium or urea as the sole nitrogen source. Uptake data are expressed as $\mathrm{mmol} / 100$ plants.

\begin{tabular}{|c|c|c|c|c|}
\hline & \multicolumn{2}{|c|}{ Maize } & \multicolumn{2}{|c|}{ Sugar-beet } \\
\hline & $\mathrm{NH}_{4}$ & urea & $\mathrm{NH}_{4}$ & urea \\
\hline Shoots & 3317 & 2209 & 3308 & 2292 \\
\hline Roots & 2635 & 1406 & 3436 & 2618 \\
\hline Whole plants & 3138 & 1940 & 3340 & 2384 \\
\hline Uptake & 457 & 271 & 69 & 50 \\
\hline
\end{tabular}

urea-supplied plants. This phenomenon was most clear for maize plants.

Big differences were observed in morphology of maize roots in dependence of the supplied nitrogen source. Roots of ammonium-supplied plants were stubby and brown-coloured, whilst urea-supplied plants were provided with a well-developed and white-coloured root system with many thin roots.

\section{Nitrogen}

In Table 3 the nitrogen contents in ammonium-supplied and urea-supplied maize and sugar-beet plants are given. Shoots and roots of both plant species contained considerably more nitrogen when supplied with ammonium than with urea. The lower nitrogen content in the shoots of urea-supplied plants did not lead to visible symptoms associated with nitrogen deficiency.

Total absorption of nitrogen as urea was much lower than as ammonium, indicating that urea is not so readily taken up as ammonium.

\section{Inorganic chemical composition}

Table 4 shows the effects of the nitrogen acquisition on the contents of the main inorganic nutritive elements in shoots and roots of maize and sugar-beet plants. Maize. Substitution of urea for ammonium sulphate in the nutrient solution resulted in a substantial increase in the total inorganic cation content $(\Sigma C)$ in the shoots. This was mainly due to a much higher potassium accumulation in ureasupplied plants, although also a positive effect of urea nutrition on the content of the divalent ions calcium and magnesium was observed. In the roots only potassium contributed to a higher total inorganic cation content in the urea treatment. Both shoots and roots of urea-supplied plants contained more of all inorganic anions ( $\Sigma A)$ than ammonium-supplied plants with the exception of sulphate, of which the content in the shoots of ammonium-supplied plants was about two times as high as in the urea treatment.

Sugar-beet. The higher total inorganic cation content in the shoots of urea-supplied plants in comparison with the ammonium treatment was mainly the result of a higher content of potassium, calcium, and magnesium. Surprisingly, ammonium nutrition resulted in a higher sodium accumulation in the shoots. The same picture was observed for the roots, although at a lower level. Phosphate and sulphate contributed to a higher total inorganic anion content in the shoots 
Table 4. Chemical composition (meq/ $\mathrm{kg} \mathrm{DM}$ ) of shoots and roots of maize and sugar-beet plants, grown on a nutrient solution with either ammonium or urea as the sole nitrogen source. $\Sigma \mathrm{C}, \Sigma \mathrm{A}=$ total cation and anion content, respectively.

\begin{tabular}{|c|c|c|c|c|c|c|c|c|}
\hline & \multicolumn{4}{|l|}{ Maize } & \multicolumn{4}{|c|}{ Sugar-beet } \\
\hline & \multicolumn{2}{|l|}{$\mathrm{NH}_{4}$} & \multicolumn{2}{|l|}{ urea } & \multicolumn{2}{|l|}{$\mathrm{NH}_{4}$} & \multicolumn{2}{|l|}{ urea } \\
\hline & shoots & roots & shoots & roots & shoots & roots & shoots & roots \\
\hline $\mathrm{K}$ & 1052 & 631 & 1883 & 972 & 722 & 441 & 1674 & 685 \\
\hline $\mathrm{Na}$ & 0 & 43 & 2 & 26 & 764 & 180 & 386 & 73 \\
\hline $\mathrm{NH}_{4}$ & 21 & 16 & 0 & 3 & 0 & 0 & 0 & 0 \\
\hline $\mathrm{Ca}$ & 72 & 34 & 190 & 42 & 208 & 28 & 524 & 46 \\
\hline $\mathrm{Mg}$ & 134 & 74 & 260 & 71 & 509 & 149 & 709 & 251 \\
\hline$\Sigma \stackrel{C}{C}$ & 1279 & 798 & 2335 & 1114 & 2203 & 798 & 3293 & 1055 \\
\hline $\mathrm{H}_{2} \mathrm{PO}_{4}$ & 448 & 351 & 847 & 468 & 1080 & 377 & 1221 & 331 \\
\hline $\mathrm{Cl}$ & 330 & 140 & 487 & 307 & 298 & 199 & 289 & 153 \\
\hline $\mathrm{SO}_{4}$ & 104 & 81 & 59 & 127 & 45 & 0 & 106 & 0 \\
\hline$\Sigma A$ & 882 & 572 & 1393 & 902 & 1423 & 576 & 1616 & 484 \\
\hline$\Sigma(\mathrm{C}-\mathrm{A})$ & 397 & 226 & 942 & 212 & 780 & 222 & 1677 & 571 \\
\hline
\end{tabular}

of urea-supplied plants in comparison with the ammonium treatment. In the roots a reverse effect of the nitrogen acquisition on the total inorganic anion content was observed, due to a lower phosphate and chloride accumulation. In sugar-beet roots no sulphate could be detected.

\section{Absorption of nutritive ions}

The amounts of the different ionogenic nutrients taken up by maize and sugarbeet plants are presented in Table 5 . These values are calculated from the Tables 2 and 4 using total nitrogen data (Table 3 ) for the calculation of ammonium absorption by the ammonium-supplied plants. Since urea was supplied in molecular form, nitrogen data were not included in the calculation of the ionic uptake balance for urea-supplied plants. Sulphate absorption was calculated as the sum of sulphate and organic sulphur, the latter being estimated as $5.4 \%$ of the organic nitrogen (total $\mathrm{N}$ minus $\mathrm{NH}_{4}-\mathrm{N}$ ) amount (Dijkshoorn \& van Wijk, 1967).

In all cases differential uptake of cations and anions resulted in an alkaline nutrient uptake pattern $\left(\mathrm{C}_{\mathrm{a}}-\mathrm{A}_{\mathrm{a}}\right)$, which was more pronounced for ammoniumsupplied than for urea-supplied plants. In both plant species ammonium absorption was only partly compensated for by a higher potassium, calcium, and magnesium accumulation in the urea-supplied plants; in ammonium-supplied sugar-beet plants sodium uptake was even higher than in the urea treatment. Substitution of urea for ammonium sulphate in the nutrient solution resulted in a small decrease in sulphate absorption by the maize roots, but a considerable positive effect on the accumulation of phosphate and chloride was observed. The overall effect was that urea-supplied maize plants had absorbed more nutri- 
Table 5. Nutrient absorption (meq/100 plants) by maize and sugar-beet plants, grown on a nutrient solution with either ammonium or urea as the sole nitrogen source. $C_{a}, A_{a}=$ total cation and anion absorption, respectively.

\begin{tabular}{|c|c|c|c|c|}
\hline & \multicolumn{2}{|c|}{ Maize } & \multicolumn{2}{|c|}{ Sugar-beet } \\
\hline & $\mathrm{NH}_{4}$ & urea & $\mathrm{NH}_{4}$ & urea \\
\hline $\mathbf{K}$ & 137 & 220 & 13 & 29 \\
\hline $\mathrm{Na}$ & 2 & 1 & 13 & 6 \\
\hline $\mathrm{NH}_{4}$ & 457 & 0 & 69 & 0 \\
\hline $\mathrm{Ca}$ & 9 & 20 & 3 & 8 \\
\hline $\mathrm{Mg}$ & 17 & 28 & 9 & 12 \\
\hline $\mathrm{C}_{\mathrm{a}}$ & 622 & 269 & 107 & 55 \\
\hline $\mathrm{H}_{2} \mathrm{PO}_{4}$ & 61 & 101 & 19 & 20 \\
\hline $\mathrm{Cl}$ & 41 & 59 & 6 & 5 \\
\hline $\mathrm{SO}_{4}$ & 39 & 26 & 5 & 5 \\
\hline$A_{a}$ & 141 & 186 & 30 & 30 \\
\hline$C_{a}-A_{a}$ & 481 & 83 & 77 & 25 \\
\hline
\end{tabular}

tive anions $\left(A_{a}\right)$ than ammonium-supplied plants. The uptake of the different anions by sugar-beet plants was not affected by the source of nitrogen nutrition.

\section{Net proton extrusion}

Both maize and sugar-beet plants extruded considerably more acidity when grown on an ammonium-containing nutrient solution as compared with urea nutrition (Figs 1 and 2). The differences in dry matter production characteristics between both plant species are clearly reflected in the proton production curves. The calculated values for excess cation absorption until harvest corresponded well with the respective cumulative amounts of base necessary to adjust the $\mathrm{pH}$ of the nutrient solutions at the initial value (Table 6).

\section{Experiment 2}

\section{Longitudinal transport of water and nitrogenous compounds}

In Fig. 3 the cumulative production of bleeding sap by maize plants is given.

Table 6. Calculated and recorded alkaline nutrient uptake (mmol/100 plants) by maize and sugarbeet plants, grown on a nutrient solution with either ammonium or urea as the sole nitrogen source.

Maize Sugar-beet

\section{Ammonium}

\begin{tabular}{lcc}
$\mathrm{C}_{\mathrm{a}}-\mathrm{A}_{\mathrm{a}}$ (calculated) & 481 & 77 \\
$\mathrm{H}^{+}$efflux (recorded) & 496 & 86 \\
Urea & & \\
$\mathrm{C}_{\mathrm{a}}-\mathrm{A}_{\mathrm{a}}$ (calculated) & 83 & 25 \\
$\mathrm{H}^{+}$efflux (recorded) & 69 & 16 \\
\hline
\end{tabular}




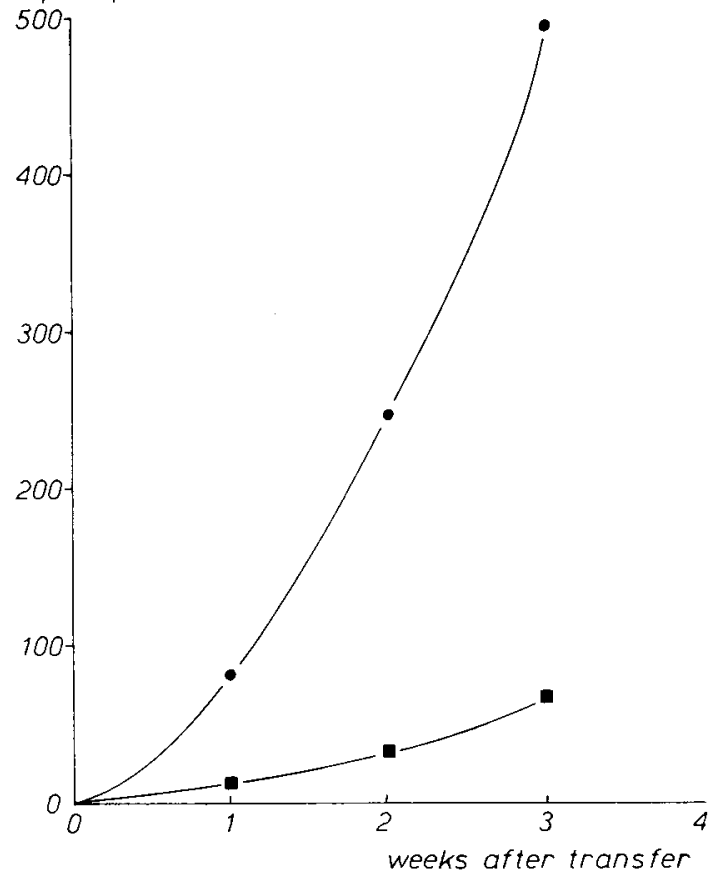

$\mathrm{H}^{+}$production

(meq/100 plants)

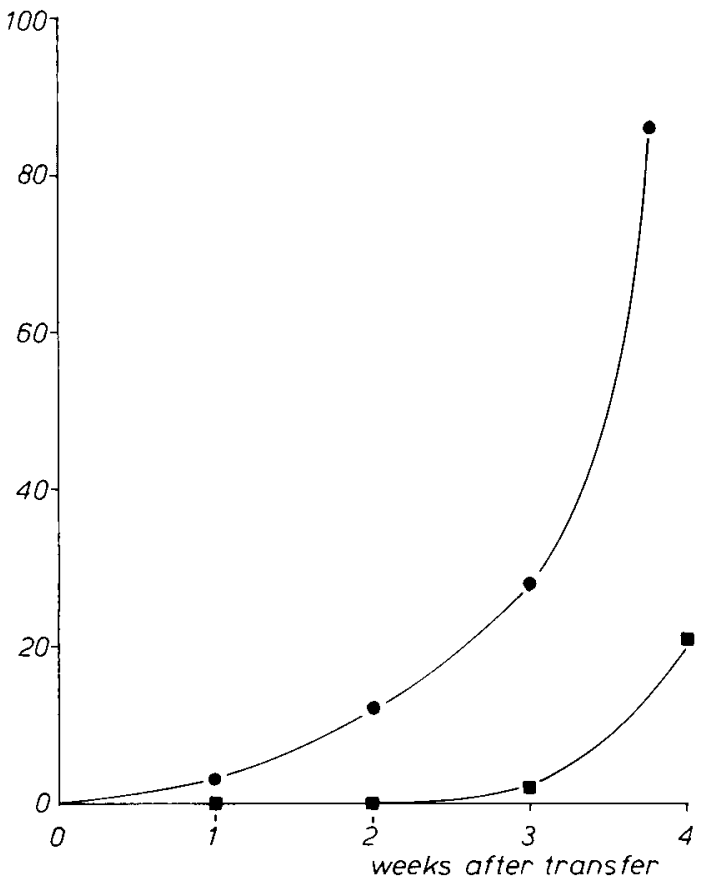

Fig. 1. Cumulative net proton production by maize plants, grown on a nutrient solution with either ammonium (O) or urea (ש) as the sole nitrogen source.

Fig. 2. Cumulative net proton production by sugar-beet plants, grown on a nutrient solution with either ammonium (C) or urea $(\boldsymbol{D})$ as the sole nitrogen source. 


\section{L. VAN BEUSICHEM AND J. J. NEETESON}

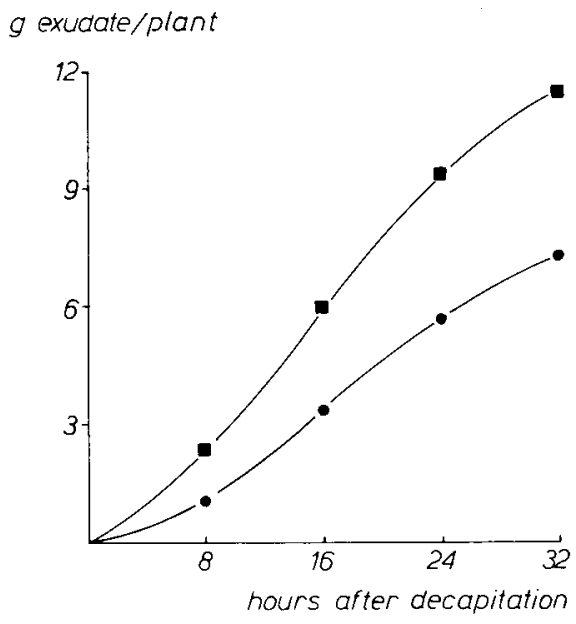

Fig. 3. Cumulative exudation by maize plants, grown on a nutrient solution with either ammonium (O) or urea (ם) as the sole nitrogen source.

The exudate production curves of both ammonium- and urea-supplied plants show a lag phase during the first hours and are almost linear during the period between 8 and 24 hours after decapitation. After 24 hours the exudation rate decreased slightly. The same picture was observed for the translocation rates of the different nitrogenous compounds (Fig. 4). In the linear part urea-supplied plants exuded 1.5 times as much as ammonium-supplied plants ( 3.5 versus $2.3 \mathrm{~g}$ per plant per $8 \mathrm{~h}$ ). As can be concluded from Table 7 longitudinal transport of total nitrogen through urea-supplied plants during the 'steady state' period was two times as high as through ammonium-supplied plants. The results show

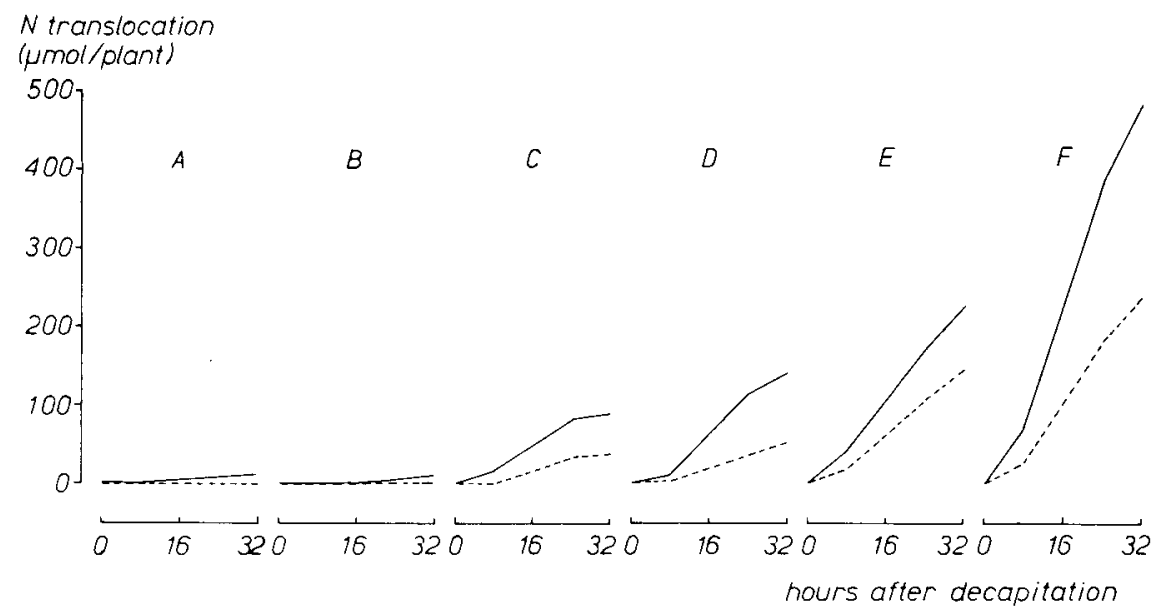

Fig. 4. Time course of longitudinal transport of nitrogenous compounds through maize plants, grown on a nutrient solution with either ammonium $(--)$ or urea $(\stackrel{-}{-}$ ) as the only nitrogen source. A: urea-N; B: $\mathrm{NH}_{4}-\mathrm{N}$; C: glutamine-N; D: asparagine-N; E: rest-N; F: total N. 
Table 7. Longitudinal transport of nitrogenous compounds through maize plants, grown on a nutrient solution with either ammonium or urea as the sole nitrogen source. Values represent the period of stationary water and solute transport (8-24 $\mathrm{h}$ after decapitation).

\begin{tabular}{|c|c|c|c|c|}
\hline & \multicolumn{2}{|l|}{ Ammonium } & \multicolumn{2}{|l|}{ Urea } \\
\hline & $\mu \mathrm{mol} / \mathrm{plant}$ & $\%$ & $\mu \mathrm{mol} /$ plant & $\%$ \\
\hline Urea-N & 0 & 0 & 7 & 2 \\
\hline Ammonium & 2 & 1 & 3 & 1 \\
\hline Glutamine-N & 35 & 22 & 67 & 21 \\
\hline Asparagine- $\mathrm{N}$ & 35 & 22 & 104 & 33 \\
\hline Rest-N & 87 & 55 & 133 & 43 \\
\hline Total-N & 159 & 100 & 314 & 100 \\
\hline
\end{tabular}

clearly that in the roots both ammonium- and urea-nitrogen were almost quantitatively metabolized and recovered as amides and other nitrogenous compounds, which contributed for $97-99 \%$ of the longitudinal transport of nitrogen. Values for rest- $\mathrm{N}$ in Table 7 probably represent negatively charged amino acids, since in all cases these values corresponded stoichiometrically with ash alkalinity data.

Big differences in age and nutritional status of the maize plants used in the ionic balance experiment (1) and in the exudation experiment (2) do not allow comparisons of nitrogen contents in the plant shoots (Table 3 ) with rates of translocation of nitrogenous compounds through the xylem (Table 7).

\section{Discussion}

\section{Experiment 1}

\section{Dry matter production}

The results presented show clearly that under the described experimental conditions total dry matter production of maize and sugar-beet plants was not significantly affected by the form of nitrogen nutrition (Table 2). It should be pointed out, however, that ammonium is not the most beneficial nitrogen source for sugar-beet (Ulrich \& Mostafa, 1980). This may explain the relatively slow start and low yields of these plants.

The big visual differences in maize-root morphology between the treatments were reflected in the dry weights of the roots, although not as drastically as reported for rough lemon and bush bean (Wallace \& Ashcroft, 1956), tomato (Kirkby \& Mengel, 1967), and white goosefoot (Kirkby, 1967). This confirms earlier findings that maize is a good grower when supplied with ammonium as the sole source of nitrogen (van Beusichem \& van Loon, 1978). Results of recent work by Ikeda \& Osawa (1981) show that only plants which do not show growth inhibition when supplied with ammonium are able to take up this compound preferentially from ammonium-nitrate mixtures and thereby causing a substantial acidification of the ambient medium. Tolerancy to ammonium ions seems 
thus to be based on the potential of the plant root to sustain an intensive proton extrusion pump operation.

\section{Ionic balance}

Both maize and sugar-beet plants showed an alkaline nutrient uptake pattern when supplied with either ammonium or urea as the sole source of nitrogen (Figs 1 and 2). Moreover, calculated values for excess cation uptake (Table 5) corresponded well with the respective amounts of net proton production by the roots (Table 6). Since partial hydrolysis of urea and subsequent uptake of ammonium would have yielded values for recorded proton production exceeding those for calcultated excess cation uptake, the conclusion is justified that under the described experimental conditions no urea decomposition had occurred. These results provide thus evidence for the ability of maize and sugar-beet plants to absorb urea as an undestructed molecule, at a rate sufficient for growth.

Ammonium-supplied plants had absorbed considerably more nitrogen than urea-supplied plants (Table 3 ). This implies that when both nitrogen sources are absorbed by a common mechanism, as supposed by Hentschel (1976), the affinity of the uptake system is different for ammonium ions and urea molecules. From the results of the present ionic balance experiment evidence for the existance of a common uptake system for ammonium and urea cannot be obtained.

\section{Experiment 2}

\section{Xylem transport of nitrogenous compounds}

Examination of xylem exudates of many ammonium-supplied plant species has learned that in the root tissue the absorbed ammonium ions are readily incorporated in organic compounds, probably via the GS/GOGAT (glutamine synthetase/glutamine $\alpha$-oxoglutarate amino transferase) pathway (Lea \& Miflin, 1974; Miflin \& Lea, 1976).

$$
\begin{aligned}
& \begin{array}{l}
\text { glutamate }+\mathrm{NH}_{3}+\mathrm{ATP} \\
\text { glutamine }+\alpha \text {-oxoglutarate }+\mathrm{NAD}(\mathrm{P}) \mathrm{H} \longrightarrow \mathrm{GOGAT} \\
+\mathrm{H}^{+}
\end{array} 2 \text { glutamine }+\mathrm{ADP}+\mathrm{P}_{\mathrm{i}} \\
& \begin{array}{l}
\mathrm{NH}_{3}+\alpha \text {-oxoglutarate }+\mathrm{ATP}+\mathrm{NAD}(\mathrm{P}) \mathrm{H}+\mathrm{H}^{+} \longrightarrow \\
\text { glutamate }+\mathrm{ADP}+\mathrm{P}_{\mathrm{i}} \\
+\mathrm{NAD}(\mathrm{P})^{+}
\end{array}
\end{aligned}
$$

The very low ammonium concentration in the xylem sap of ammonium-supplied plants (Fig. 4, Table 7) is a clear reflection of this phenomenon.

Furthermore, the results presented in Fig. 4 and Table 7 provide evidence for an almost complete metabolization of urea in the roots. At least two pathways for assimilation of urea can occur, including hydrolytic decomposition catalysed by urease followed by incorporation of ammonium, and direct incorporation of urea via the reversal of the ornithine cycle. 


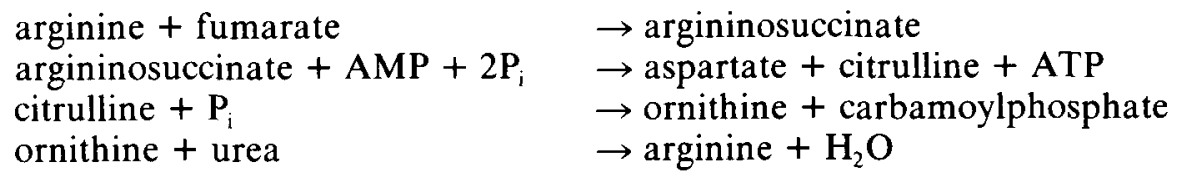

$\begin{aligned} \text { urea }+ \text { fumarate }+\mathrm{AMP}+3 \mathrm{P}_{\mathrm{i}} \rightarrow & \begin{array}{l}\text { aspartate }+ \text { carbamoylphosphate }+ \\ \text { ATP }+\mathrm{H}_{2} \mathrm{O}\end{array}\end{aligned}$

When urea is assimilated via enzymatic breakdown, fractionation of nitrogenous compounds in the xylem exudates of urea- and ammonium-supplied plants should be similar, since ammonium is one of the products of urease activity. However, the contribution of amides and rest- $\mathrm{N}$ (amino acids) to the total transport of nitrogen through the xylem differed for both treatments (Table 7). This allows the assumption that in the root tissue urea is assimilated via the reversal of the ornithine cycle or another mechanism including the conversion of ornithine into arginine, rather than via urea hydrolysis followed by ammonium incorporation via the GS/GOGAT mechanism.

\section{Acknowledgements}

We like to thank Mr J. A. Nelemans and Mr E. M. Wittich for their technical and analytical assistance. The senior author wishes to express his sincere gratitude to Eric Ooms for moral support during less pleasent periods.

\section{References}

Beusichem, M. L. van, 1981. Nutrient absorption by pea plants during dinitrogen fixation. 1. Comparison with nitrate nutrition. Neth. J. agric. Sci. 29: 259-272.

Beusichem, M. L. van \& L. J. M. van Loon, 1978. Nutrient-element balance in the maize plant in relation to ammonium, urea, or nitrate nutrition. Proceedings of the 1 lth Congress of the ISSS (Edmonton) Vol. 1: 307-308

Breteler. H., 1973. A comparison between ammonium and nitrate nutrition of young sugar-beet plants grown in nutrient solutions at constant acidity. 1. Production of dry matter, ionic balance and chemical composition. Neth. J. agric. Sci. $21: 227-244$.

Chouteau, J., 1963. Etude de la nutrition nitrique et ammoniacale de la plante de tabac en présence des doses croissantes de bicarbonate dans le milieu nutritif. Annls. Inst. exp. Tabac Bergerac 4 No 2 .

Clark, H. E., 1936. Effect of ammonium and nitrate nitrogen on the composition of the tomato plant. Pl. Physiol. 11: 5-24.

Coïc, Y., C. Lesaint \& F. Le Roux, 1962. Effects de la nature ammoniacale ou nitrique de l'alimentation azotée et du changement de la nature de cette alimentation sur le métabolisme des anions et cations chez la tomate. Annls. Physiol. vég. 4: 117-125.

Court, M. N., R. C. Stephen \& J. S. Waid, 1964. Toxicity as a cause of the inefficiency of urea as a fertilizer. I. Review. J. Soil Sci. 15: 42-48.

DeKock, P. C.. 1970. The mineral nutrition of plants supplied with nitrate or ammonium nitrogen. In: E. A. Kirkby (Ed.), Nitrogen nutrition of the plant. The University of Leeds, pp. 39-44.

Dijkshoorn, W. \& A. L. van Wijk, 1967. The sulphur requirements of plants as evidenced by the sulphur-nitrogen ratio in the organic matter - a review of published data. Plant \& Soil 26: 129157. 
Dijkshoorn, W., D. J. Lathwell \& C. T. de Wit, 1968. Temporal changes in carboxylate content of rye grass with stepwise change in nutrition. Plant \& Soil 29: 369-390.

Eastin, E. F., 1978. Total nitrogen determination for plant material containing nitrate. Analyt. Biochem. 85: 591-594.

Gausman, H. W. \& R. I. Batteese, 1966. Uptake of radioactive urea by potato plants. Maine Farm Res. 14:29-31.

Hentschel, G., 1970. The uptake of ${ }^{15} \mathrm{~N}$-labelled urea by bush beans. In: E. A. Kirkby (Ed.), Nitrogen nutrition of the plant. The University of Leeds, pp. 30-34.

Hentschel, G., 1976. Aufnahme and Verteilung von ${ }^{15} \mathrm{~N}$-markiertem Harnstoff bei Phaseolus vulgaris L. Z. Pfl.Ernähr. Bodenkd. 139: 239-251.

Houba, V. J. G., F. van Egmond \& E. M. Wittich, 1971. Changes in production of organic nitrogen and carboxylates $(\mathrm{C}-\mathrm{A})$ in young sugar-beet plants grown in nutrient solutions of different nitrogen compositon. Neth. J. agric. Sci. 19: 39-47.

Ikeda, H. \& T. Osawa, 1981. Nitrate- and ammonium-N absorption by vegetables from nutrient solution containing ammonium nitrate and the resultant change of solution $\mathrm{pH}$. J. Japan. Soc. hort. Sci. 50: 225-230.

Kirkby, E. A., 1967. A note on the utilization of nitrate, urea and ammonium nitrogen by Chenopodium album. Z. Pfl.Ernähr. Bodenkd. 117: 204-209.

Kirkby, E. A., 1968. Influence of ammonium and nitrate nutrition on the cation-anion balance and nitrogen and carbohydrate metabolism of white mustard plants grown in dilute nutrient solutions. Soil Sci. 105: 133-141.

Kirkby, E. A., 1969. Ion uptake and ionic balance in plants in relation to the form of nitrogen. In: I. H. Rorison (Ed.), Ecological aspects of the mineral nutrition of plants. Proc. Symp. Br. ecol. Soc. 9: 215-235.

Kirkby, E. A. \& A. D. Hughes, 1970. Some aspects of ammonium and nitrate nutrition in plant metabolism. In E. A. Kirkby (Ed.), Nitrogen nutrition of the plant. The University of Leeds, pp. 69 77.

Kirkby, E. A., \& K. Mengel, 1967. Ionic balance in different tissues of the tomato plant in relation to nitrate, urea, or ammonium nutrition. Pl. Physiol. 42: 6-14.

Kirkby, E. A. \& K. Mengel, 1970. Preliminary observations on the effect of urea nutrition on the growth and nitrogen metabolism of sunflower plants. In: E. A. Kirkby (Ed.), Nitrogen nutrition of the plant. The University of Leeds, pp. 35-38.

Kiss, S., M. Drăgan-Bularda \& D. Rădulescu, 1975. Biological significance of enzymes accumulated in soil. Adv. Agron. 27: 25-87.

Kyllingsbaek, A., 1975. Extraction and colorimetric determination of urea in plants. Acta Agric. scand. 25: 109-112.

Lea, P. J. \& B. J. Miflin, 1974. An alternative route for nitrogen assimilation in higher plants. Nature 251: 614-616.

Miflin, B. J. \& P. J. Lea, 1976. The pathway of nitrogen assimilation in plants. Phytochemistry 15: 873-885.

Mitsui, S. \& K. Kurihara, 1962. The intake and utilization of carbon by plant roots from ${ }^{14} \mathrm{C}$-labelled urea. IV. Absorption of intact urea molecule and its metabolism in plant. Soil Sci. Plant Nutr. 8:219-225.

Müller, E., 1961. Zum Problem der 'aktiven' Wasseraufnahme. I. Die Wasseraufnahme und ihre Beziehung zur Harnstoffaufnahme. Untersuchungen an den Blütenstandsschäften von Taraxacum officinale. Flora 150: 372-388.

Ostromeçka, M., 1961. Nitrogen intake from urea and ammonium nitrate by oat in water cultures. Roczn. Nauk. 82A: 473-488.

Ulrich, A. \& M. A. E. Mostafa, 1980. Ammonium and nitrate as sources of nitrogen for sugarbeets. $J$. Am. Soc. Sugar Beet Technol. 20: 553-570.

Wallace, A. \& R. T. Ashcroft, 1956. Preliminary comparisons of the effects of urea and other nitrogen sources on the mineral compositon of rough lemon and bean plants. Proc. Am. Soc. hort. Sci. 68: 227-233. 